\title{
Relation of qualitative and quantitive levels of availability and adequacy of food in determing the level of food safety
}

\author{
Nataliia Solomianiuk ${ }^{1}$, Fedulova Iryna ${ }^{2}$, Olena Dragan ${ }^{1}$
}

1 - National University of Food Technologie, Kyiv, Ukraine

2 - Kyiv National University of Trade and Economics, Kyiv, Ukraine

Keywords:

Food

Safety

Availability

Adequacy

\section{Article history:}

Received

12.10.2018

Received in

revised form

14.01.2019

Accepted

31.05.2019

\section{Corresponding author:}

Nataliia

Solomianiuk

E-mail:

nsolomianiuk@

gmail.com

\section{DOI:}

$10.24263 / 2304-$

974X-2019-8-2-

16

\section{Abstract}

Introduction. It is necessary to have a set of indicators that will allow to consider qualitive and quantitive approaches for food availability and adequacy assessment for qualitative analysis of food safety.

Materials and methods. The object of the research is the analysis of food safety and indicators of food adequacy and availability by which it is carried out. Methods of statistical analysis in the part of designing trends of the share of food consumption in total households expenditures for 2000-2017 with the defining it sanalytical equation and the cost per unit of energy of the daily diet consumer prices in Ukraine were used during the research.

Results and discussions. The physical aspect of availability to food is determined by the possibility of the country to produce and deliver the food products of corresponding quality to the population and in the volume, which is necessery for providing of valuable person's nutrition. Economic aspect is determined by purchasing power of the population, id est by possibility to buy at the market or produce personally foodstuffs in the appropriate quantity and assortment, that provide the normal standard of person's living. For estimation of physical availability, the norms of overhead between rational or optimal nutrition, norms of minimum food consumption, calorie content of food of person's ration, providing of calorie content $\%$ of dayly ration due to the consumption of animal origin products are used. For estimation of economic availability standard of prices on foodstuffs, specific proportion of charges on foodstuffs in the combined charges of households, coefficients of nutrition differentiation according to social groups are used. They do not represent the state of food availability in complete measure. Thus, the calculations showed that in Ukraine, in 2000, $1 \%$ of total food exenses in the budget of totaled household expenses accounted about $41 \mathrm{kcal}$, then in 2017-52.5, which is $28 \%$ of the 2000 level. So, the availability of food in 2017 improved compared with 2000 . The growth rates of 1,000 kcal, which in 2000-2014 and 2017 the growth rates of consumer prices increased, which is evidence in those periods not the price generates food availability as the level of income, especially in terms of food costs.

Conclusions. The complex use of these indexes will allow more fully estimate the level of food availability of population and work out the events of timely prevention of the educed threats. 


\section{Introduction}

Food safety envisages, that the government must guarantee the production of sufficient amount of food for satisfaction of population's growing necessities. Thus, without obstacles and at the reasonable prices foreign trade must satisfy population's necessity with specific products that is not produced into the country, due to import. The functioning of the certain system of providing necessary backlogs with the aim of implementation of unexpected downstreams or sharp rises in prices is also envisaged. An important value is acquired by the physiology and solvent limits of demand on foodstuffs at the internal market that is characterized by the indexes of existent pattern of consumption and its physiology norms. Social aspect embraces the question of solvent access of population to food nutrition, social defence of scanty categories of population, strengthening of social politics addressness, achievement of equal level with city's terms of getting the real money incomes and social service, equal terms of public welfare in the village for all groups of population regardless of labour type activity and residence and other.

Undertaken research is based on the materials of the last publications, that concern the different aspects of determination and forming of food safety in the different countries of the world. Theoretical basis of the article is based on the defined notions of essence, structure, public policy and program of forming and development of food safety, that was considered in such researches: [1-4].

World experience of food safety forming was integrated in the documents of Food and Agriculture Organisation: [5-7].

The questions of research of food safety development status in Ukraine that define its basic problems, ways of their approaches to the government control of this area are studied by the following researchers: [8-11].

Important for undertaken the research was determination of methodical approaches for the evaluation of food availability level of population. In numeral researches of scientists, the questions of systematization of indicators for the evaluation of food safety overall, in particular it was carried out and were examined in the next researches: [12-16].

Analysis of these publications allowed to make conclusion, that the system of evaluation of food availability needs further development and expansion from position of combination of two aspects of physical and economic availability.

\section{Materials and methods}

The object of reseach is the analysis of food safety and indicators by which it is carried out. Indicators of food availability and adequacy are considered in details among the indicators adopted for food safety assessment.

Methods. For estimation of physical accessibility, the norms of the upper limit or optimal nutrition, norms of minimal food consumption, caloric content of human food rations, \% of caloric intake of the daily ration of animal origin are sued. To assess the economic availability: the level of food prices, the share of food costs in total household expenses, the rates of nutrition differentiation by social groups. The analysis of existing approaches has allowed to offer additional for more complete qualitative and quantative analysis of adequacy and availability of food. The calculation of the proposed indicators was carried out on the example of Ukraine. The results of the research can be applied to other countries. 
During the research, the methods of statistical analysis of existing indicators of food availability and sufficiency on the example of Ukraine were used.

The statistical analysis was used for developing of trends of the share of food expenditure in total household expenses for 2000-2017, with its analytical equation, the trend of the unit of energy of the daily diet and consumer prices on the example of Ukraine. The purchasing power of $1 \mathrm{kcal}$ was calculated by the formula:

$$
K=\frac{K c a l}{S V}
$$

where $\mathrm{K}$ is the quantity of kcal, which accounts for $1 \%$ of the cost of food for the population in the total household expenses; Kcal - number of kcal energy of the daily diet of the average consumer; SV is the share of food expenditure in the total amount of total household expenses. The average cost of 1,000 kcal consumed (Vkcal) was calculated by the formula:

$$
\text { Vkcal }=\frac{F V}{K c a l}
$$

where FV - daily food expenditure in the total household expenditure per person.

Comparative analysis is used for correlation of trends of average cost of 1 thousand kcal and consumer price index for food.

\section{Results and discussions}

\section{Principles of food safety forming and food availability as its part}

Food safety is the level of food providing of population, that guarantees socio-political stability in society, survival and development of nation, person, families, steady economic development of the country. Food security is defined as the state in which people at all times have physical, social and economic access to sufficient and nutritious food that meets their dietary needs for a healthy and active life [17].

It expresses security of vital interests of a person that is expressed in guaranteeing of unimpeded economic access of a person by the state to the foodstuffs with the aim of maintenance of its ordinary vital activity.

In accordance with the draft law of Ukraine «About food safety of Ukraine» such basic principles of food safety forming are determined [18]:

1. Providing of interests of Ukraine in the system of international food safety in the conditions of globalization and regional economic integration;

2. Food independence of the country;

3. Economic validity of the national necessities which is related with providing of Ukraine with food, sufficientness and stability of food supplies;

4. Timelinesses and adequacy of events in relation to forming of food safety to the real and potential, internal and external threats;

5. Physical and economic availability of quality and safe food products for all categories of population in the amount of necessary for providing of active and healthy life.

These principles can be grouped according to the functional loading in relation to implementation of certain tasks in forming of food safety. Namely, thus: self-sufficiency; physical sufficientness; economic availability; balanced; quality; ecofriendlyness.

Thus, food safety is regarded as a science, policy, environmental and social program [19]. 
Self-dependance. Every country must provide population being based on the own production of basic foodstuffs. Food self-dependance envisages satisfaction of basic part of requirements in foodstuffs, that predetermines independence of the country from external suppliers in satisfaction of population necessities due to domestic production. This principle envisages the absence of dependence on the import of food stuffs. For prevention of dependence situation the country can grow the economic potential and promote efficiency of agroindustrial production. To achieve this, it is needed larger harvest of crops, vegetables and livestock products, with predictable increase of meat consumption per capita $(\mathrm{kg} / \mathrm{person} /$ year) of $37 \mathrm{~kg}$ nowadays up to about $52 \mathrm{~kg}$ in 2050 (26-44 kg) in developing countries [20].

The main feature that at the same time there must be presented and imported commodities at the domestic market, in fact the consumer has a right for choice, and domestic commodity will become competitive only in the case, when will be distinguished by quality and contemporaneity of assortment. The substantiation of the UK food safety program provided the identification of priority research issues with a focus on food industry development [21].

The physical sufficientness means possibility of population to buy at the market or produce in the personal household foodstuffs that are needed in the appropriate quantity and assortment, that needed for satisfaction of human physiology necessities. Under vital necessary of foodstuffs we understand such products without which population can not exist, in particular, that: compensate the charges of organism energy in the process of its vital functions; assist natural recreation and active longevity of population; give an opportunity to provide harmonious development of children physiologically; assist prophylaxis and treatment of different diseases. The physical sufficientness of food envisages its trouble-free entering places of consumption in volumes that answer solvent demand and physiology norms. According to the Global Food Security Index (GFSI) methodology, availability is shown as such that easures the sufficiency of the national food supply, the risk of supply disruption, national capacity to disseminate food and research efforts to expand agricultural output [17].

Economic availability means access to the food resources of all layers of population due to present solvent demand. According to the Global Food Security Index (GFSI) methodology, affordability is shown as such that measures the ability of consumers to purchase food, their vulnerability to price shocks and the presence of programmes and policies to support customers when shocks occur [17].

The determinative factor of economic availability of food is the level of economic and social development of country's society. Possibility of different layers of population to consume foodstuffs in necessary volume and assortment depends on it, purchasing them on market prices, producing in own subsidiary households and others like that. There is the permanent deepening of differentiation of population income in Ukraine, so as the difference between extreme groups with the lowest and the greatest levels of income is substantial enough. The increase of economic availability of food nutrition must be founded, first of all, on the increase of population income, foremost its poorest layers and the reasonable suggested retail prices on foodstuffs, and also to the powerful program of their budgetary address support [22]. However, the relationship between food prices and income of the population is not always predictable, that is, the convenience and availability of food in particular place also play an important role [23].

Quality envisages providing of such totality of products properties that is stipulated to satisfy its ability to satisfy the necessities in accordance with setting appropriation. Realized through the achievement of valuable level of food nutrition of population due to the 
consumption of high-quality foodstuffs. Quality, as an economic category is one of the basic factors of products competitiveness of agrarian sphere, and the problem of its increase is complex, so as it includes scientific, technical, social and economic parts [24]. Presently, it is impossible to produce quality goods without the use of high-quality agricultural raw material, innovative technologies and modern equipment and highly skilled personnel.

Balanced. The balanced food is based on that the meal consists of different food substances: fats, proteins, carbohydrates, vitamins, fat acids, mineral salts, microelements and others like that [25]. Irreplaceable substances, that does not appear in the person's organism, but get there with foodstuffs, have the special value. Irreplaceable amino acids and fat acids (linolic, linolenic) belong to such substances. To the group of irreplaceable substances vitamins, mineral elements that support and balanced molecular composition of different fabrics of person's organism, take also, compensating their losses in the process of vital functions. On the basis of the balanced food theory the daily allowance norms of the use of separate substances are worked out [26]. The principle of balanced also includes calorie content of foodstuffs. Calorie content shows the power value of food products or rations of food: the amount is warm, that it is distinguished by food or forage substances, when they oxidize in the organism of a person or animal. Safety of food and calorie content are basis of providing normally food nutrition of population.

Ecofriendlyness. We consider that it is important to add another constituent in the system of the country's food safety principles. According to the principle of ecofriendlyness all must be submitted to the principle of minimum loading on ecology and maximal "naturalness" of both product and process of foodstuffs production. Also the ecofriendlyness envisages that the consumption of electro- and heat power is taken to the minimum due to the events on energy-savings and use of energykeeping technologies. Now it is a niche of small farms and middle sizes plants. But a niche broadens constantly, as consumers are ready to overpay for a natural product without chemistry and for the idea of nature maintenance. Although, nowdays in Ukraine this is mainly fascination for solvent people and fashion statement, but annually production of ecological goods cost decrease and they become accessible to greater amount of consumers. Environmental agriculture is closely connected with nutrition and health and health must be seen as economic resource [27].

On the basis of the considered principles the group of indicators that characterize the certain degree of country's food safety providing is formed.

\section{Essence, aspects and threats of food availability}

Availability as category means reaching desirable for a person. Food availability needs to be examined in physical and economic aspects. Physical aspect is determined by possibility of the country to produce and deliver food products to population in the volume, to the necessity of valuable food nutrition providing for a person, corresponding quality. Economic aspect is determined by purchasing power of population, id est by possibility to buy at the market or produce in the personal household foodstuffs in appropriate quantity and assortment, that provide the normal standard of living and person's health. It is access to the food resources of all layers of population due to present solvent demand.

The main factors of threat to food safety are existence of groups of population, that are under the limit of poverty and do not have sufficient income for purchasing of minimum set of foodstuffs; the structural unbalanced food nutrition according to separate constituents; low and unstable quality of foodstuffs; exhaustion of domestic agrarian production potential simultaneously with its technological degradation. Therefore, the increase of economic and physical food availability on the basis of increase of foodstuffs production and improvement 
of their quality volumes is strategic priority of social and economic development of the country.

\section{Physical availability}

Index of physical availability is the relation of physical and desirable levels of food consumption. Desires of everybody in this sphere can be inefficient or indefinite. For this purpose there are the so-called the special purpose of reference-points, namely medical norms of food nutrition. Such norms are developed by specialists on the hygiene of food nutrition for aged and professional groups, geographical and social terms are taken into account.

There are two kinds of nutrition norms [28]:

1. Norm of top level between rational or optimal food nutrition, exceeding of that generates the problems of overnutrition and overweight. The achievement of such norms means that the task of food availability is attained and takes place the state of population's food providing.

2. Norms of minimum food consumption, that determine the lower limit of necessary receipt of nutritives. Such norms are examined as a cut-off norms.

The norms of top limit of rational food nutrition have character of recommendations. The minimum norms of food consumption accounts in Ukraine on the basis of law "About Cost of Living" and become firmly established by the resolution of Cabinet of Ministers [28].

The level of the population's consumption of food products is determined as the combined index of actual consumption of separate types of food products in calculation per capita, and also dayly calorie content of food ration, taking into account its balanced on maintenance proteins, fats, carbohydrates, vitamins, macro- and microelements [29].

The level of physical availability can be estimated by means of estimation of satisfaction level of foodstuffs consumption to the rational norms (Table 1).

\section{State of physical availability of food}

Table 1

\begin{tabular}{|l|c|c|c|c|c|c|c|c|}
\hline \multirow{2}{*}{ Food Products } & \multicolumn{3}{|c|}{$\begin{array}{c}\text { Average food consumption } \\
\text { per capita per month, kg }\end{array}$} & \multicolumn{4}{c|}{$\begin{array}{c}\text { Indicator of consumption } \\
\text { adequacy,\% }\end{array}$} \\
\cline { 2 - 10 } & 2000 & 2010 & 2015 & 2017 & 2000 & 2010 & 2015 & 2017 \\
\hline Meat and meat products & 3,3 & 5,1 & 4,6 & 4,7 & 49,3 & 76,1 & 68,7 & 70,1 \\
\hline Milk and milk products & 17,1 & 19,2 & 19,8 & 19,3 & 53,9 & 60,6 & 62,5 & 60,9 \\
\hline Eggs & 18 & 20 & 19 & 20 & 74,4 & 82,6 & 78,5 & 82,6 \\
\hline Fish and fish products & 1,3 & 1,7 & 1,2 & 1,3 & 76,5 & 100,0 & 70,6 & 76,5 \\
\hline Sugar & 3,5 & 3,1 & 2,8 & 2,8 & 109,4 & 96,9 & 87,5 & 87,5 \\
\hline $\begin{array}{l}\text { Oil and other vegetable } \\
\text { fats }\end{array}$ & 1,8 & 1,8 & 1,6 & 1,5 & 163,6 & 163,6 & 145,5 & 136,4 \\
\hline Potatoes & 10,4 & 7,6 & 6,6 & 6,4 & 101,0 & 73,8 & 64,1 & 62,1 \\
\hline Vegetables and melons & 9,5 & 10,3 & 8,8 & 8,5 & 70,9 & 76,9 & 65,7 & 63,4 \\
\hline $\begin{array}{l}\text { Fruits, berries, nuts, } \\
\text { grapes }\end{array}$ & 2,5 & 3,5 & 3,1 & 3,7 & 33,3 & 46,7 & 41,3 & 49,3 \\
\hline $\begin{array}{l}\text { Bread and bread } \\
\text { products }\end{array}$ & 10,7 & 9,3 & 8,5 & 8,4 & 127,4 & 110,7 & 101,2 & 100,0 \\
\hline
\end{tabular}

Data for 2015, 2017, excluding part of the temporarily occupied territories in the Donetsk and Luhansk oblasts

Source for calculation: [30] 
An analysis showed that the most critical level of physical availability in Ukraine was observed for fruit, berries, nuts and vine. On meat and meat products, milk and milk products, potato, also there is a level of the dissatisfied consumption of vegetables. The reasons of such situation is low investment attractiveness of market through the necessity of considerable capital, high risks and absence of country's support of agricultural producers at presence of low purchasing power of population. The consumption of eggs, sugar is close to rational norms, on bread is the same. According to oil and other vegetable oil, we exceed the norms of rational consumption considerably.

On the estimations of FAO and Worldwide Organization of Health Protection, the middle norm of food nutrition for one person must present 2300-2400 kcal on the period of twenty-four hours [5]. This index differs depending on sex, age, profession, and also natural and climatic conditions. In the case, when the index becomes below than $1800 \mathrm{kcal}$, then the clearly expressed malnutrition is shown up, and when this index passes the limit to $1000 \mathrm{kcal}$ on the period of twenty-four hours is obvious hunger (physical shortage of meal) [31]. Reasons of hunger are natural, political cataclysms, wars, financial crisis, reduction of consumption through uneven distribution of food.

From data of FAO food nutrition must be valuable and in the structure of food ration the norm of albumen content must be not less of $100 \mathrm{gs}$ on the period of twenty-four hours [31]. Food nutrition, when we have the lack of not only calories but also proteins, first of animal origin, and also fats, vitamins, microelements, is called poor nutrition. It is conditioned by permanent malnutrition and monotony of ration (one type of product prevails in the consumption).

It is necessary to notice that in the USA this index presents $3900 \mathrm{kcal}$, in the countries of European Union is $3500 \mathrm{kcal}$ [32]. The actual middle index of calorie content of food ration in the world presents $2700 \mathrm{kcal}$ on the period of twenty-four hours, in the economically developed countries is on the average about 100 grams present per capita is $3400 \mathrm{kcal}$, and consumption of proteins on the period of twenty-four hours. It is important to mark, that in the developed countries there are social groups with a proof low level consumption that need permanent help from the side of the country [33]. For the analysis of the diet balance, we use the average daily caloric intake of the ration of the entire population with the definition of its parts at the expense of products of animal and plant origin, without taking into account gender, age, occupation and climatic conditions. Such simplification does not limit the quality of the conclusions, since in the future there is the comparison of the average daily caloric value from the calculation for the whole population and the average household expenditure on food as well on average per person.

The maximum (cut-off criterion) criterion of daily calorie content of food ration in Ukraine presents $2500 \mathrm{kcal}$ on period of twenty-four hours [29], thus $55 \%$ of daily ration must be provided due to the consumption of animal origin products (table 2).

As it is shown from the table 2 all investigated years the calorie content of population ration of Ukraine was higher than maximum level of $2500 \mathrm{kcal}$. After the economic crisis of 2008-2009 the calorie content of foodstuffs consumption decrease gradually, military situation in Ukraine after 2014 also complicated proceeding in calorie content of ration of average Ukrainian person.

On the whole, in 2017 the population of Ukraine consumed foodstuffs calorie content which is on $8,3 \%$ more than maximum level. However, other situation with the pattern of consumption, as $55 \%$ must belong to the products of animal origin. In Ukraine this norm is not executed, for investigated period Ukrainians consumed at most $41 \%$ in 1990 and minimum $23 \%$ in 2000 of foodstuffs of animal origin. The positive tendency is that at the beginning of 2000 of foodstuffs of animal origin consumption increases gradually. In 2017 due to the products of animal origin the average daily food value of ration presented $28,9 \%$ instead of recommended $55 \%$ of general ration. 
Table 2

Dynamics of caloricity of average daily consumption of food products by the population of Ukraine per capita, kcal

\begin{tabular}{|l|c|c|c|c|c|c|}
\hline \multicolumn{1}{|c|}{ Indexes } & $\mathbf{2 0 0 0}$ & $\mathbf{2 0 0 5}$ & $\mathbf{2 0 1 0}$ & $\mathbf{2 0 1 5}$ & $\mathbf{2 0 1 6}$ & $\mathbf{2 0 1 7}$ \\
\hline Total caloric content & 2661 & 2916 & 2933 & 2799 & 2742 & 2707 \\
\hline $\begin{array}{l}\text { \% to the limit level } \\
\text { (threshold level 2500) }\end{array}$ & 106,4 & 116,6 & 117,3 & 112,0 & 109,7 & 108,3 \\
\hline $\begin{array}{l}\text { Caloric content of products } \\
\text { of animal origin }\end{array}$ & 611 & 733 & 809 & 791,0 & 790,0 & 781,0 \\
\hline \% to total caloric content & 23 & 25,1 & 27,6 & 28,3 & 28,8 & 28,9 \\
\hline $\begin{array}{l}\text { \% to the limit level } \\
\text { (boundary level 1365) }\end{array}$ & 44,8 & 53,7 & 59,3 & 57,9 & 57,9 & 57,2 \\
\hline $\begin{array}{l}\text { Caloric content of vegetable } \\
\text { products }\end{array}$ & 2050 & 2183 & 2124 & 2008 & 1952 & 1926 \\
\hline \% to total caloric content & 77 & 74,9 & 72,4 & 71,7 & 71,2 & 71,1 \\
\hline
\end{tabular}

Data for 2015, 2017, excluding part of the temporarily occupied territories in the Donetsk and Luhansk oblasts

Source for calculation: [34]

\section{Economic availability}

Considerable part of food in rural locality and its greater part in cities are bought, then price in the prominent factor of economic food availability. Satisfaction of consumers' necessities and successful realization of commodity suggestion depend on the cost of product, that can be examined in two aspects: from the point of view of consumers and from the point of view of businessmen that produce and will realize the prepared or finished products. For consumers the price means possibility in different measures to satisfy their necessities. Consumer is ready to pay higher price for the products of high quality. From the point of view of businessman, acceptable price gives the opportunity to realize finished products and get sufficient profit.

One of food safety indicators of the country is determining the specific ratio of charges on foodstuffs in the combined charges of households, it must not exceed 60\% (Figure 1). The critical limit of gross income use of economies is determined at this value. 


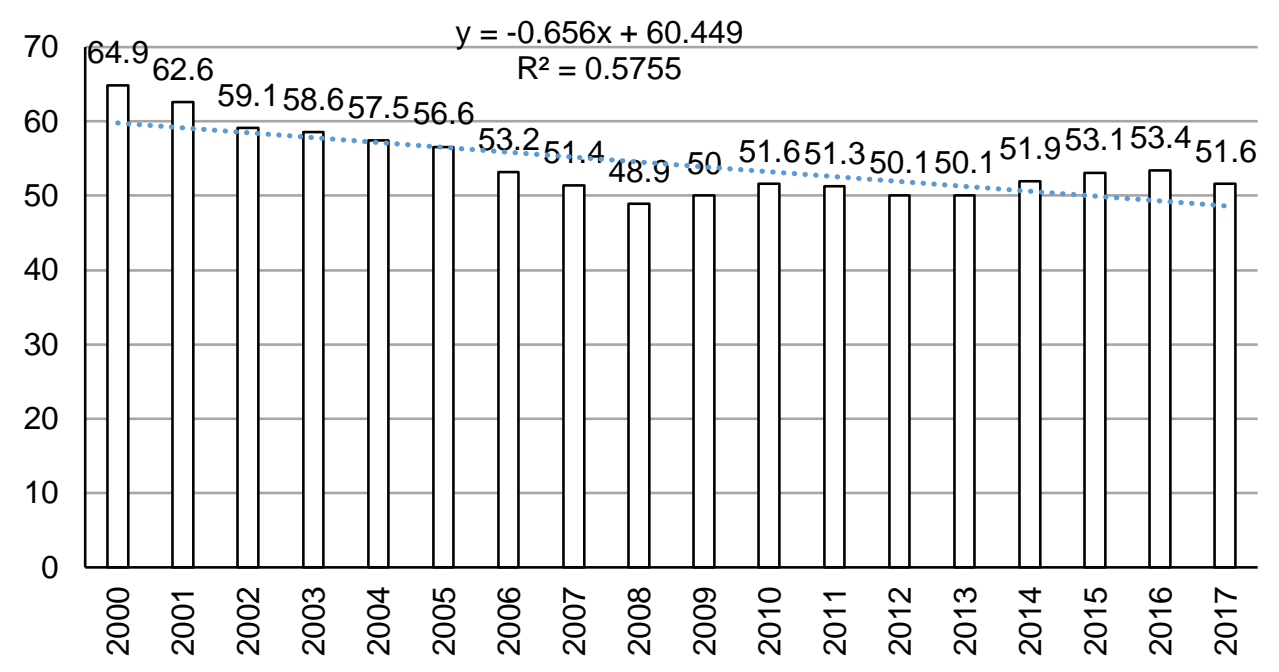

Figure 1. Specific weight of food expenses in total household expenses for 2000-2017 years Data for 2015, 2017, excluding part of the temporarily occupiedterritories in the Donetsk and Luhansk oblasts

Source for calculation: [30]

In 2000-2001 critical value of this index was observed, after this there was a descending tendency to 2008, after that an insignificant increase took place in 2017 - this index is presented $51,6 \%$. Worsening of price food availability compelled the population to promote part of food charges in family budget. In world statistics such part serves as the important indicator of the level of country's development. For the poorly developed countries the low level of consumption of food combines with high part of food products charges in the lump sum of family's charges. Thus, in 2017 it presented 13,4\% in France, 8,1\% in Great Britain, $17,1 \%$ in Poland, 22,2\% in Lithuania. The average value of this index in the countries of EU- 28 in 2017 was 12,2\% [35].

Important aspect of food safety is availability of valuable nutrition for population with low-income. There is certain differentiation in the consumption of foodstuffs by the population of Ukraine, that it is also possible to define by means of special indicator which is determined by the resolution № 1379 [29].

The index of differentiation of nutrition cost according to social groups is accounted as a correlation between by the nutrition cost of $20 \%$ of households with the largest income and cost of nutrition of $20 \%$ of households with the least income (Table 3 ).

The main differentiation of foodstuffs consumption is observed in the groups of fruit, berries, nuts, grapes. Households of the fifth quintile group consume fruit and berries on the average more than in two times than households of the first quintile group. Also, wide difference in the consumption of meat and meat products (in 2017 more than $71 \%$ ), milk and dairy products (more than 63\%), fish and fish products (more than 50\%), vegetables and melon-field (more than 52\%). At the low middle level of food consumption its large differentiation destroys quality of food of the poorest layers of population for the cut-off criteria of food safety and it creates an impending condition. If to examine the tendencies of consumption differentiation, then in 2017 the decline took place only for meat, dairy products, eggs and fruit, for other products it became sharp. 
Differentiation factor of food by social groups

\begin{tabular}{|l|c|c|c|c|c|}
\hline \multicolumn{1}{|c|}{ Food Products } & $\mathbf{2 0 1 3}$ & $\mathbf{2 0 1 4}$ & $\mathbf{2 0 1 5}$ & $\mathbf{2 0 1 6}$ & $\mathbf{2 0 1 7}$ \\
\hline Meat and meat products & 1,82 & 1,81 & 1,76 & 1,67 & 1,71 \\
\hline Increase / decrease to the previous year & - & $-0,01$ & 0,05 & 0,09 & $-0,04$ \\
\hline Milk and milk products & 1,67 & 1,62 & 1,62 & 1,70 & 1,63 \\
\hline Increase / decrease to the previous year & - & $-0,05$ & 0,00 & 0,08 & $-0,07$ \\
\hline Eggs & 1,28 & 1,22 & 1,24 & 1,29 & 1,22 \\
\hline Increase / decrease to the previous year & - & $-0,06$ & 0,02 & 0,05 & $-0,07$ \\
\hline Fish and fish products & 1,57 & 1,75 & 1,60 & 1,60 & 1,50 \\
\hline Increase / decrease to the previous year & - & 0,18 & $-0,05$ & 0,00 & $-0,10$ \\
\hline Sugar & 1,27 & 1,40 & 1,39 & 1,39 & 1,29 \\
\hline Increase / decrease to the previous year & - & 0,13 & $-0,01$ & 0,00 & $-0,10$ \\
\hline Oil and other vegetable fats & 1,19 & 1,20 & 1,13 & 1,21 & 1,07 \\
\hline Increase / decrease to the previous year & - & 0,01 & $-0,07$ & 0,8 & $-0,14$ \\
\hline Potatoes & 1,06 & 1,16 & 1,11 & 1,18 & 1,05 \\
\hline Increase / decrease to the previous year & - & 0,10 & $-0,05$ & 0,07 & $-0,13$ \\
\hline Vegetables and melons & 1,46 & 1,55 & 1,59 & 1,52 & 1,52 \\
\hline Increase / decrease to the previous year & - & 0,09 & 0,04 & $-0,07$ & 0,00 \\
\hline Fruits, berries, nuts, grapes & 2,57 & 2,59 & 2,29 & 2,29 & 2,15 \\
\hline Increase / decrease to the previous year & - & 0,02 & $-0,30$ & 0,00 & $-0,14$ \\
\hline Bread and bread products & 1,09 & 1,12 & 1,05 & 1,08 & 1,02 \\
\hline Increase / decrease to the previous year & - & 0,03 & $-0,07$ & 0,03 & $-0,06$ \\
\hline
\end{tabular}

Data for 2015, 2017, excluding part of the temporarily occupied territories in the Donetsk and Luhansk oblasts

Source for calculation: [36]

\section{Indicators of food availability providing}

Important task of food safety is increase of quantitative and quality descriptions of population's food nutrition at simultaneous decline of specific proportion of charges on food in family budget. Quality description of sufficientness of food nutrition is average daily calorie content of ration of middle Ukrainian person, the index of physical sufficientness of food nutrition and purchasing power that is expressed as income can come forward as quantitative descriptions.

Thus, the integral index of nutrition availability can be the index of purchasing power of $1 \mathrm{kcal}$. It can be determined as a relation of amount kcal energy of daily food ration of average person's nutrition to specific ratio of charges on nutrition in the general volume of the combined charges of households. This index will be shown by what amount of kkal will be on $1 \%$ charges on food (Figure 2). 


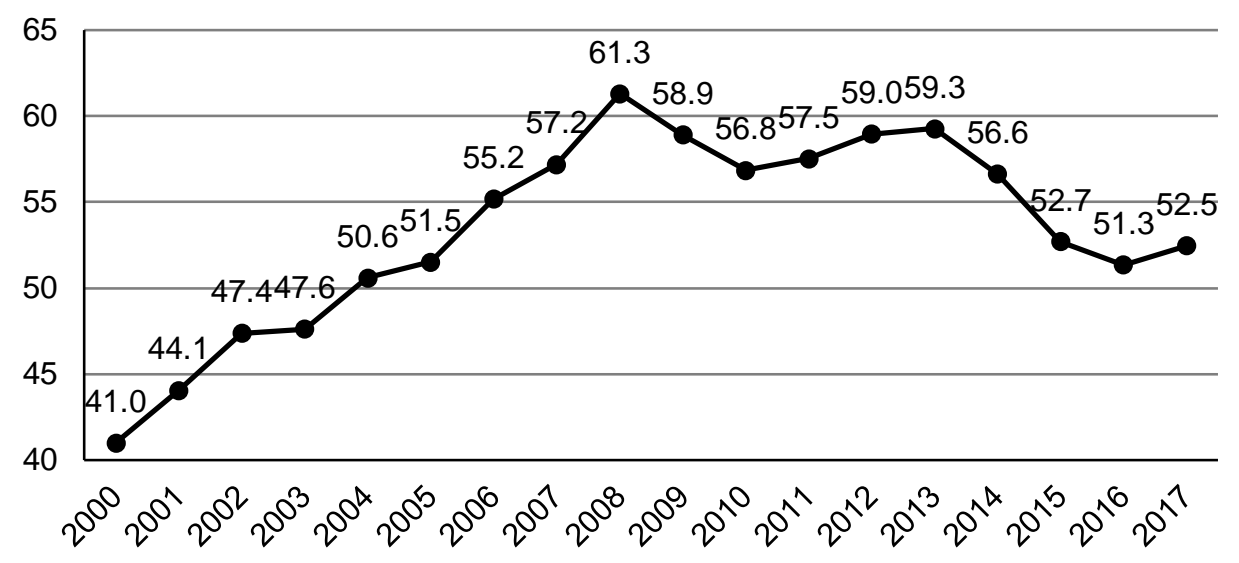

Figure 2. The amount of kcal that accounts for $1 \%$ of the total food expenditure of the population in the total household expenditure in Ukraine

Data for 2015, 2017, excluding part of the temporarily occupied territories in the Donetsk and Luhansk oblasts

Source for calculation [30]

From data of figure 2 it is possible to monitor as availability of nutrition changed during 2000-2017. Thus, if in 2000 on $1 \%$ of charges on food in the budget of the combined charges of households it was $41 \mathrm{kcal}$, then in 2017 - 52,5, that on $28 \%$ of the level of 2000 . And availability of food nutrition in 2017 became better in comparison with 2000. It is interesting that according to this index it is possible to compare availability of food nutrition between separate regions and countries.

Thus, in the USA at daily consumption of food in $3800 \mathrm{kcal}$ the specific proportion of charges on food in the income of households was $14,1 \%$ or $270 \mathrm{kcal}$ on $1 \%$. Accordingly on this index of food availability of the USA prevail Ukraine almost in 5 times [37].

Dynamics of energy unit cost of daily food ration of average person in comparison with cost-of-living-indexes also can serve as the important indicator of food availability that links the quality and quantitative level of nutrition availability (Figure 3). This index shows how the price and income are important for ordinary person's nutrition.

Thus, for 2010-2017 the cost of 1 thousands kcal had grown almost in 2,3 times, certainly inflation processes influenced on this in Ukraine. But, as the research showed, the rates of increase of 1 thousands kcal cost for investigated period except 2015-2016 passed ahead the rates of consumer price, it is certificate that not only price forms food availability but also the level of income forming. And the energy cost of daily ration grows quicker than inflation processes in the country. 

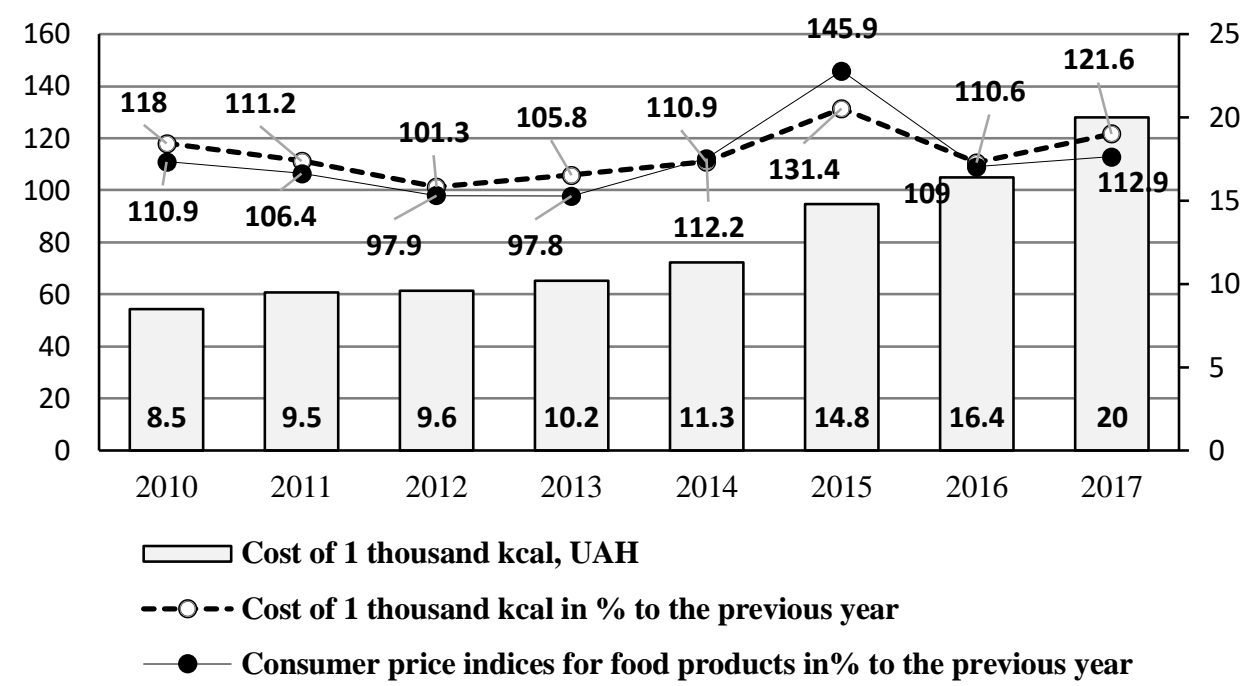

Figure. 3. Dynamics of cost per unit of energy of the daily diet and consumer prices in Ukraine Data for 2015, 2017, excluding part of the temporarily occupied territories in the Donetsk and Luhansk oblasts

Source for calculation: [30; 36]

\section{Conclusions}

Reasons of unsatisfactory food availability of the country can be: deficit of food; low level of solvent demand, that is determined by the standard of prices and income; dependence of internal market on the imported food delivery; low level of products competitiveness in quality or/and by price at sufficientness of food of own production. It is important to monitor those tendencies correctly that in actual fact influence on this index.

Indicators of food availability, offered in this research, combine a physical and economic aspect and they differ from other existing.

The amount of kcal, that is on $1 \%$ of expenses on population nutrition of households and the cost of energy unit on daily nutrition ration and its correlation in the combination of charges with the standard of consumer prices to other existent indicators of food availability will allow to monitor the problems that arise up in the country in relation to provide the population with food, and, accordingly, to develop events that are needed to use for availability of valuable and quality person's nutrition.

\section{References}

1. Defra (2009), Food Security: Defra Discussions, Department for Environment, Food and Rural Affairs, London,

Available at: http://www.defra.gov.uk/foodrin/policy/security.htm

2. Havas K., Salman M. (2011), Food security: its components and challenges, International Journal of Food Safety Nutrition and Public Health, 4, pp. 4-11, DOI: 10.1504/IJFSNPH.2011.042571 
3. Farouk S. (2011), The Food and Financial Crises and the South: Causes and Impacts, Kasarinlan: Philippine Journal of Third World Studies, 26(1-2), pp. 22-48.

4. Vivas E. (2009), Food Crisis: Causes, Consequences and Alternatives. International Viewpoint, Available at: http://www.internationalviewpoint. org/spip.php?article1774

5. (2003), FAO Methodology for the Measurement of Food Deprivation, Rome.

6. (2006), FAO Policy Brief, Issue 2

7. (2009), FAO Declaration of the World Summit on Food Security, Rome, Available at: http://www.fao.org/fileadmin/.pdf

8. Zelenska O.O. (2012), Systema prodovolchoyi bezpeky: sutnist ta iyerarxichni rivni, Visnyk ZhDTU, 1(59), pp.108-112

9. Kundyeyeva G. (2016), Prodovolcha bezpeka: innovacijnyj rozvytok i zminy u spozhyvanni xarchovyx produktiv, Zbirnyk naukovyx pracz Cherkaskogo derzhavnogo texnologichnogo universytetu, Seriya: Ekonomichni nauky, 42(2), pp. 29-36.

10. Shebanina O. V. (2007), Formuvannya i efektyvnyj rozvytok prodovolchogo pidkompleksu APK: Monografiya, Kyiv.

11. Mudrak R.P. (2013), Prodovolcha bezpeka Ukrayiny v umovax globalizaciyi, Ekonomichnyj chasopys XXI, 1-2(1), pp. 34-37,

Available at: http://nbuv.gov.ua/UJRN/ecchado_2013_1-2(1),_12.

12. Bytov V.P. (2013), Indykatory ta kryteriyi prodovolchoyi bezpeky region, Ekonomichnyj forum, 3, pp. 48-53,

Available at: http://nbuv.gov.ua/UJRN/ecfor_2013_3_9;

13. Barrett C.B. (2010), Measuring food insecurity, Science, 327(5967), pp. 825-828, DOI: 10.1126/science. 1182768

14. Pasquale De Muro, Matteo Mazziotta (2010), Towards a Food Insecurity Multidimensional Index (FIMI),

Available at: http://www.fao.org/fileadmin/templates/ERP/uni/FIMI.pdf

15. Webb P., Coates J., Frongillo E.A., Rogers B.L., Swindale A., Bilinsky P. (2006), Measuring household food insecurity: why its so important and yet so difficult to do, The Journal of Nutrition, 136(5), pp. 1404S-1408S,

DOI: $10.1093 / \mathrm{jn} / 136.5 .1404 \mathrm{~S}$

16. Global Food Security Index (2018), Building resilience in the face of rising food-security risks, The Economist Intelligence Unit Limited, Available at: file://C:/Users/1/Desktop/EIU\%20Global\%20Food\%20Security\%20Index\%20\%202018\%20Findings\%20\&\%20Methodology.pdf.

17. Global Food Security Index, Available at: https://foodsecurityindex.eiu.com/Home/Methodology.

18. Available at: http://w1.c1.rada.gov.ua/pls/zweb2/ webproc4_1?pf3511=44744

19. Ingram J. (2011), A food systems approach to researching food security and its interactions with global environmental change. Food Security, 3(4), pp. 417-431, DOI: 10.1007/s12571-0110149-9

20. Bruinsma J. (2009), The resource outlook to 2050: By how much do land, water and crop yields need to increase by 2050?, Food and Agriculture Organization of the United Nations (FAO), Available at: http://www.fao.org/3/a-ak971e.pdf

21. John S. I. et. al (2013), Ingram Priority research questions for the UK food system, Food Security, 5(5), pp. 617-636, https://doi.org/10.1007/s12571-013-0294-4

22. Darmon N., \& Drewnowski A. (2008), Does social class predict diet quality? The American Journal of Clinical Nutrition, 87(5), pp. 1107-1117.

DOI: 10.1093/ajen/87.5.1107

23. Herforth A., \& Ahmed S. (2015), The food environment, its effects on dietary consumption, and potential for measurement within agriculture-nutrition interventions, Food Security, 7(3), pp. 505-520, DOI: 10.1007/s12571-015-0455-8.

24. Hamid El Bilali (2019), Research on agro-food sustainability transitions: where are food security and nutrition? Food Security, pp. 1-19. DOI: 10.1007/s12571-019-00922-1 
25. Joanne E. Arsenault, Robert J. Hijmans Kenneth H. (2015), Brown Improving nutrition security through agriculture: an analytical framework based on national food balance sheets to estimate nutritional adequacy of food supplies, Food Security, 7(3), pp. 693-707, DOI: 10.1007/s12571015-0452-y

26. Committee on World Food Security (2012), Coming to terms with terminology: Food security, nutrition security, food security and nutrition, food and nutrition security, Available at:

http://www.fao.org/fsnforum/sites/default/files/file/Terminology/MD776CFS_Coming_to_term s_with_Terminology),.pdf.

27. Dangour A.D., Green R., Hasler B., Rushton J., Shankar B., Waage J. (2012), Linking agriculture and health in low- and middle-income countries: an interdisciplinary research agenda, The Proceedings of the Nutrition Society, 71(2), pp. 222-228, DOI: 10.1007/s12571-015-0473-6

28. Available at: http://www.rada.gov.ua

29. Available at: http://zakon4.rada.gov.ua/laws/show/1379-2007-ח

30. Statystychnyj zbirnyk "Vytraty i resursy domogospodarstv Ukrayiny, Available at: www.ukrstat.gov.ua/druk/publicat/kat_u/publdomogosp_u.htm.

31. FAO Food Balance Sheet data. available at: www.fao.org/faostat/en/\#data/FBS/metadata

32. Shevchenko O.O. (2008), Ekonomichna dostupnist prodovolchogo zabezpechennya, Derzhavne budivnycztvo, 2, Available at: http://nbuv.gov.ua/UJRN/DeBu_2008_2_29

33. Shhekovych O.S. (2009), Vykorystannya zarubizhnogo dosvidu derzhavnogo regulyuvannya ekonomiky APK v Ukrayini, Ekonomika APK, 1. pp.140-146.

34. Balansy ta spozhyvannya osnovnyx produktiv xarchuvannya naselennyam Ukrayiny za 2017 rik, Derzhavnyj komitet statystyky Ukrayiny, Kyiv, Available at: www.ukrstat.gov.ua.

35. Prodovolcha bezpeka v Ukrayini u 2017 roci. Oglyad osnovnyx indykatoriv, Available at: http://edclub.com.ua/analityka/prodovolcha-bezpeka-v-ukrayini-u-2017-roci-oglyad-osnovnyhindykatoriv

36. Statystychnyj shhorichnyk Ukrayiny za 2017 rik, Derzhavne pidpryyemstvo «Informacijnoanalitychne agentstvo», Kyiv, Available at: www.ukrstat.gov.ua;

37. Beregovyj V.K. (2010), Cina ta zabezpechennya produktamy xarchuvannya naselennya Ukrayiny, Naukovyj visnyk Nacionalnogo universytetu bioresursiv $i$ pryrodokorystuvannya Ukrayiny, 154(1), pp. 34-42. 